\title{
RELEVANSI INFORMASI PERBANKAN PADA MANAJEMEN PERBANKAN DI INDONESIA
}

\author{
Ishak Ramli \\ Fakultas Ekonomi, Universitas Tarumanagara \\ Email: ishakr@fe.untar.ac.id
}

\begin{abstract}
ABSTRAK
Studi ini bertujuan membuktikan digunakannya informasi wajib yang diatur bank sentral (Bank Indonesia) untuk disampaikan tepat waktu dari periode ke periode, untuk mengendalikan kinerja bank. Laporan 105 bank di Indonesia dari tahun 2000 - 2012 digunakan untuk membuktikan informasi berguna untuk meningkatkan kinerja bank. Kinerja bank diukur dengan RORWA pada periode laporan di analisis dengan analisis regresi berganda terhadap informasi (laporan wajib kepada bank sentral) tentang efisiensi (BOPO), modal (CAR), deposito (DEPOSIT dan DEPOSIT FUNDING), pembiayaan usaha kecil (KUK), likuiditas (LDR), kualitas aset (NPL), dan profitabilitas (NIM dan ROA) yang dilaporkan periode sebelumnya. Hasilnya ditemukan bahwa semua informasi tersebut signifikan mempengaruhi kinerja bank. Semua informasi wajib dan ketat dari perbankan kepada bank sentral ternyata juga digunakan oleh perbankan dalam mengendalikan kinerja bank.
\end{abstract}

Kata kunci: laporan Bank sentral, informasi kegiatan bank, manajemen bank, dan kinerja bank

\section{PENDAhuluan}

Informasi yang tepat dan relevan sangat dibutuhkan perusahaan untuk mengambil keputusan yang tepat dan baik untuk kemajuan perusahaan. MAIS (Management Accounting Information System) dapat membantu para manajer dalam hal pengambilan keputusan yang tepat. MAIS merupakan suatu sistem yang dapat mengubah data menjadi salah satu informasi yang berguna dalam membuat keputusan (Tetyana, 2013). Pengambilan keputusan yang baik akan mempengaruhi kinerja manajerial, dan MAIS yang relevan dapat mempengaruhi keputusan yang baik (Chenhall dan Morris, 1986). Terdapat hubungan positif yang signifikan antara manfaat informasi MAS (Management Accounting System) dan kinerja MAS (Zhu, dkk, 2009). Perusahaan menggunakan informasi $M A S$ dalam berbagai bentuk untuk mengambil keputusan. Para manajer mengharapkan bantuan $M A S$ pada saat sebelum, selama, dan setelah tindakan yang dilakukan oleh perusahaan, untuk menentukan tujuan, untuk memahami apakah tujuan relevan, dan untuk mengukur kinerja (Dumitru, 2010).

Terkait pada risiko maka informasi pada industri perbankan juga diperlukan tepat waktu, dengan harapan informasi (laporan) yang relevan dan tepat waktudapat digunakan untukmemperbaiki kesalahan atau kesulitan secara dini. Penggunaan informasi yang tepat waktu dapat mengendalikan kinerja bank dan risiko atas kemungkinan terjadinya penyimpangan dari posisi ideal. Pengendalian risiko terjadinya penyimpangan dan risiko lainnya akan mempengaruhi kinerja operasi sebuahbank. Pengendalian risiko yang ketat harus dilakukan industri perbankan agar tidak ada bank yang akan mengalami financial distress, mengingatbank yang mengalami financial distress akan sangat mengganggu operasi bank lainnya dalam sistem keuangan yang ada serta perekonomian suatu daerah atau negara.

Ada banyak parameter ditetapkan dalam sistem operasional perbankan di Indonesia. Bank sentral menentukan banyak laporan-laporan yang diregulasi secara formal legal yang harus disampaikan kepada otoritas perbankan, jasa keuangan dan bank sentral. Permasalahannya regulasi laporan yang harus disampaikan pihak perbankan kepada bank sentral sangat ketat serta sangat banyak ( 80 item )setiap bulannya yang seyogia nya potensial digunakan sebagai parameter untuk mengukur peningkatan ataupun penurunan manajemen perbankan dalam mengendalikanatau manajemen kinerja atau risiko bank.Fenomena yang diduga seringkali terjadi adalah laporan yang disampaikan hanya sebagai frormalitas saja dan tidak digunakan untuk melakukan 
manajemen kinerja dan risiko bank tersebut. Laporan itu digunakan hanya untuk tujuan formalitas saja, tanpa digunakan sebagai parameter dalam mengendalikan operasional manajemennya sesuai harapan yaitu dapat mengendalikan kinerja dan risiko.

Fenomena tidak digunakannya informasi yang diregulasikan untuk mengambil keputusan menyebabkan ketidakefisienan ekonomi. Biaya yang cukup besar dalam menghasilkan informasi tersebut tidak diimbangi dengan peningkatan kinerja dari periode sebelumnya.Peningkatan kinerja dari periode sebelumnya menunjukkan adanya indikasi bahwa kinerja perusahaan tersebut berada dalam kondisi yang benar.Informasi yang dibuat tidak digunakan untuk tujuan pengambilan keputusan, sehinggaada banyak informasi yang terlewatkandan tidak mendorong peningkatan kinerja.Situasi informasi siap digunakan untuk tujuan pengambilan keputusannamun tidak dimanfaatkan dan fenomena pengambilan keputusan tanpa menggunakan informasi yang tepat dan relevan terjadi di Indonesia(Ramli dan Iskandar, 2014).

Laporan kinerja keuangan bankdiregulasikan untuk wajib dilaporkan kepada bank sentral (Bank Indonesia). Laporan kinerja keuangan bankdiharapkan untukdapat mengakomodasi kebutuhan akan informasi yang utuh, komprehensif dan berkualitas. Bank Indonesia memerlukan informasiinformasi guna melakukan fungsinya sebagai bank sentral, khususnya fungsi pada kebijakan moneter, sistem pembayaran, dan pengawasan perbankan, yang dapat mendukung pelaksanaan tugas dimaksud. SementaraIndustri perbankan merupakan industri yang paling ketat dikendalikan bank sentral khususnya, dengan sangat banyak laporan yang harus disampaikan. Ada sangat banyak informasi yang diharuskan Bank Indonesia sebagai bank sentral di Indonesia untuk disampaikan setiap bank di Indonesiatentang kondisi dan kinerja keuangannya terkait peraturan-peraturan pengendalian.Apakah semua informasi yang dilaporkan setiap bank kepada Bank Indonesia (sentral bank) juga digunakan oleh bank tersebut dalam mengambil keputusanmanajemen mereka sehingga dapatmeningkatkankinerja bank?

Ada banyak faktor, baik faktor-faktor internal (faktor-faktor yang berasal dari dalam perusahaan) maupun faktor-faktor eksternal (faktor-faktor yang berasal dari luar perusahaan) yang dapat mempengaruhi kinerja bank.Tingkat risiko mempengaruhi kinerja bank. Tingkat risiko yang lebih rendah menyebabkan peningkatan kinerja bank yang lebih tinggi(Odonkor, dkk, 2011; Drago, 2011 ; Csaba dan Nagy, 2003 ; Zhang, dkk, 2013).Peraturan perbankan nasional (Sum, 2015), kepemilikan bank (Micco, Panizza, dan Monica, 2007 ; Lin dan Zhang, 2009; Altan, Yusufazari, dan Aykut, 2014 ; Tunali, dkk, 2015), pembiayaan usaha kecil (Ergungor, 2002 ; Anwar, 2010 ; Berger, Cowan, dan Frame, 2011), keputusan manajemen dan dewan memiliki dampak yang signifikan terhadap kinerja masing-masing bank, sementara faktor ekonomi makro juga memiliki kontribusi signifikan (Ongore dan Kusa, 2013).Kecukupan modal dan ukuran bank(Al-Tamimi dan Charif, 2011 ; Onaolapo dan Olufemi, 2012 ; Tunali, dkk, 2015 ; Sakinc dan Gulen, 2014), dana deposito, kualitas aset yang tinggi, diversifikasi pendapatan, dan kecukupan modal positif mempengaruhi kinerja bank, sementara ukuran bank dan komposisi aset memiliki dampak yang lebih ambigu terhadap kinerja bank (Mergaerts dan Vennet, 2016).

Selain itu kualitas aset juga signifikan mempengaruhi kinerja bank, kualitas aset diukur dengan menggunakan rasio NPL (Andries, Vasile, dan Maria, 2011).Rasio ekuitas terhadap total aset, rasio deposito terhadap total aset dan rasio non-interest expenses terhadap total aset memiliki dampak yang signifikan terhadap kinerja bank. Tingkat suku bunga dan tingkat inflasi dari variabel makroekonomi juga memiliki dampak yang signifikan terhadap kinerja bank (Acaravci dan Calim, 2013; Ivanov, 2014; Tunali, dkk, 2015).Kualitas pelayanan teknis mempengaruhi kinerja bank, dan kemampuan pemasarannya memberikan efek mediasi yang kuat pada 
hubungan antara kualitas pelayanan teknis dan kinerja bank (Akroush, 2009).Profitabilitas, diukur dengan menggunakan rasioROA (Return On Assets) dan rasio NIM (Net Interest Margin)signifikan mempengaruhi kinerja bank (Li, dkk, 2001; Hamada dan Konishi, 2010; Dogan, 2013; Zhang, dkk, 2013).

Likuiditas, (Shen, dkk, 2009; Bassey, dkk, 2016),modal inti signifikan mempengaruhi kinerja bank selama krisis keuangan (Andries, Cocris, dan Ursu, 2012).Efisiensimempengaruhi kinerja bank. Bank yang memiliki efisiensi operasional yang lebih tinggi mempunyai kinerja bank yang lebih baik dibandingkan dengan rekan-rekannya(Hamada dan Konishi, 2010; Olweny dan Shipo, 2011; Fiserova, Teply, dan Tripe, 2015).

Pertanyaannya apakah informasi yang diwajibkan Bank Indonesia tentang: efisiensi(BOPO), modal (CAR), deposito (DEPOSIT dan DEPOSIT FUNDING), pembiayaan usaha kecil (KUK), likuiditas (LDR), kualitas aset (NPL), danprofitabilitas (NIM dan ROA) digunakan perbankan di Indoenesia sehingga mempengaruhi kinerja bank?

\section{Landasan Teori}

Informasi merupakan hasil periode yang lalu dimonitor dan dikendalikan sehingga dapat digunakan untuk mengendalikan kinerja di periode berikutnya.

Tingkat Efisiensi digunakan untuk mempengaruhi kinerja bank.

Informasi tingkat Efisiensi diukur dengan rasio BOPO mempengaruhi kinerja bank, bank dengan efisiensi yang lebih tinggi mempunyai kinerja bank yang lebih baik dibandingkan dengan bankbank lain (Hamada dan Konishi, 2010; Olweny dan Shipo, 2011; Fiserova, Teply, dan Tripe, 2015). Efisiensi di monitor setiap periode sehingga efisiensi bank tersebut tinggi dan dapat mempengaruhi kinerja yang baik.

\section{Tingkat Modal digunakan untuk mempengaruhi KinerjaBank}

Informasi tingkat Modal diukur dengan rasio kecukupan modal atau Capital Adequacy Ratio (CAR) berpengaruh terhadap kinerja bank. Bank yang memiliki rasio modal yang tinggi dapat mendukung investasi bank yang tinggi dan diharapkan meningkatkan kinerja bank, sehingga semakin tinggi rasio modalnya maka semakin tinggi pula kinerja bank tersebut (Dietrich dan Wanzenried, 2009; Mergaerts dan Vennet, 2015). CAR dimonitor melalui laporan CAR sehingga diharapkan dapat mempengaruhi peningkatan kinerja. Makin tinggi CAR, makin mampu bank tersebut mendanai dan melakukan investasinya sehingga diharapkan makin tinggi kinerja bank tersebut.

\section{Tingkat Deposito digunakan untuk mempengaruhi KinerjaBank}

Informasi tingkat deposito diukur dengan rasio deposito terhadap total aset berpengaruh terhadap kinerja bank. Bank yang memiliki rasio total deposito terhadap total aset yang tinggi memiliki tingkat deposito yang tinggi, dan semakin tinggi tingkat depositonya maka semakin tinggi pula kinerja bank tersebut (Acaravci dan Calim, 2013; Tunali, dkk, 2015). Informasi tingkat deposito dimonitor setiap periode melalui laporan yang diwajibkan Bank Indonesia, sehingga tingkat deposito mencapai tingkat yang diinginkan atau diharapkan dan akan meningkatkan kinerja bank tersebut.

Sedangkan, komposisi pendanaan yang diukur dengan rasio total deposito nasabah terhadap total kewajiban berpengaruh terhadap kinerja bank (Mergaerts dan Vennet, 2015). Bank-bank yang memiliki tingkat deposito nasabah yang diharapkan akan memungkinkan mereka untuk mengambil manfaat dari kegiatan pinjaman mereka. Namun, hal tersebut menggambarkan 
adanya ketergantungan yang kuat peningkatan profitabilitas dengan deposito nasabah, sehingga apabila rasio total deposito nasabah terhadap total kewajiban menjadi meningkat maka kinerja bank akan mengalami penurunan (Gatev, dkk, 2009). Informasi tingkat deposito yang dimonitor setiap periode akan mempengaruhi kinerja Bank.

\section{Pembiayaan Usaha Kecil mempengaruhi Kinerja Bank}

Pembiayaan usaha kecil mempengaruhi kinerja bank (Anwar, 2010). Penggunaan nilai kredit untuk pinjaman usaha kecil memiliki efek awal yang negatif pada kinerja bank, dan efek yang moderat dari waktu ke waktu (Berger, Cowan, dan Frame, 2011).

\section{Tingkat Likuiditas Terhadap Kinerja Bank}

Tingkat Likuiditas mempengaruhi kinerja bank. Rendahnya likuiditas menyebabkan bank harus melakukan pinjaman jangka pendek antar bank, atau mencari alat likuid lain yang biasanya memiliki biaya lebih tinggi dibandingkan dengan dana pihak ketiga. Pada akhirnya, hal tersebut mengakibatkan menurunnya pendapatan bank sehingga berdampak pada penurunan kinerja bank, maka semakin rendah likuiditas maka semakin rendah pula kinerja bank tersebut (Shen, dkk, 2009). Informasi tingkat likwiditas yang dimonitor setiap periode akan memudahkan meningkatkan kinerja bank.

\section{Kualitas Aset mempengaruhi Kinerja Bank.}

Kualitas aset mempengaruhi kinerja bank. Penurunan total kredit macet akan menurunkan rasio NPL, dan semakin rendah rasio NPL maka kinerja bank akan meningkat karena fungsi bank sebagai lembaga intermediary sudah berjalan dengan baik. Sebaliknya, peningkatan total kredit macet akan meningkatkan rasio NPL, dan semakin tinggi rasio NPL maka kinerja bank akan menurun karena fungsi bank sebagai lembaga intermediary tidak berjalan dengan baik dan bank akan dinilai gagal dalam menjalankan fungsinya tersebut (Andries, Vasile, dan Maria, 2011). Informasi kualitas aset yang dimonitor bank setiap periode akan mempermudah bank mengendalikan kinerja bank nya.

\section{Tingkat Profitabilitas mempengaruhi Kinerja Bank.}

Tingkat Profitabilitas bank mempengaruhi kinerja bank. Tingkat profitabilitas diukur dengan rasio NIM signifikan mempengaruhi kinerja bank, kinerja bank yang rendah diakibatkan oleh rendahnya rasio NIM dari bank tersebut (Li, dkk, 2001; Hamada dan Konishi, 2010). Sedangkan rasio ROA mempengaruhi kinerja bank, bank dengan ROA yang tinggi juga memiliki kinerja keuangan yang tinggi (Zhang, dkk, 2013; Dogan, 2013). Informasi tingkat profitabilitas yang dimonitor setiap periode akan meningkatkan kinerja bank tersebut, karena informasi tersebut digunakan untuk mengendalikan kinerja bank pada periode berikutnya. 


\section{Penelitian yang Relevan}

Tabel 1.

Penelitian yang relevan terkait sembilan variabel independen terhadap kinerja bank.

\begin{tabular}{|l|l|l|l|l|l|}
\hline No & Nama & Tahun & Tempat & $\begin{array}{l}\text { Variabel } \\
\text { Independen }\end{array}$ & Hasil \\
\hline 1 & Hamada dan Konishi & 2010 & Indonesia & BOPO & Signifikan \\
\hline 2 & Olweny dan Shipo & 2011 & Kenya & BOPO & Signifikan \\
\hline 3 & Fiserova, Teply, dan Tripe & 2015 & Eropa & BOPO & Signifikan \\
\hline 4 & Dietrich dan Wanzenried & 2009 & Swiss & CAR & Signifikan \\
\hline 5 & Al-Tamimi dan Charif & 2011 & $\begin{array}{l}\text { Uni Emirat } \\
\text { Arab }\end{array}$ & CAR & Signifikan \\
\hline 6 & Onaolapo dan Olufemi & 2012 & Nigeria & CAR & Tidak Signifikan \\
\hline 7 & Sakinc dan Gulen & 2014 & Turki & CAR & Signifikan \\
\hline 8 & Mergaerts dan Vennet & 2015 & Eropa & CAR & Signifikan \\
\hline 9 & Acaravci dan Calim & 2013 & Turki & DEPOSIT & Signifikan \\
\hline 10 & Ivanov & 2014 & California & DEPOSIT & Signifikan \\
\hline 11 & Tunali, dkk & 2015 & Turki & DEPOSIT & Signifikan \\
\hline 12 & Mergaerts dan Vennet & 2015 & Eropa & DEPOSIT & Signifikan \\
& & & FUNDING & \\
\hline 13 & Ergungor & 2002 & Amerika & KUK & Tidak Signifikan \\
\hline 14 & Anwar & 2010 & Indonesia & KUK & Signifikan \\
\hline 15 & Berger, Cowan, dan Frame & 2011 & Amerika & KUK & Tidak Signifikan \\
\hline 16 & Shen, dkk & 2009 & Afrika Selatan & LDR & Signifikan \\
\hline 17 & Li, dkk & 2001 & Cina & NIM & Signifikan \\
\hline 18 & Hamada dan Konishi & 2010 & Indonesia & NIM & Signifikan \\
\hline 19 & Andries, Vasile, dan Maria & 2011 & Eropa & NPL & Signifikan \\
\hline 20 & Hamada dan Konishi & 2010 & Indonesia & ROA & Tidak Signifikan \\
\hline 21 & Dogan & 2013 & Turki & ROA & Signifikan \\
\hline 22 & Zhang, dkk & 2013 & Turki & ROA & Signifikan \\
\hline
\end{tabular}

\section{Hipotesis}

Hipotesis 1 : Efisiensi (BOPO) mempengaruhi kinerja bank.

Hipotesis 2 : Modal (CAR) mempengaruhi kinerja bank.

Hipotesis 3 : Deposito (DEPOSIT) mempengaruhi kinerja bank.

Hipotesis 4 : Deposito (DEPOSIT FUNDING) mempengaruhi kinerja bank.

Hipotesis 5 : Pembiayaan usaha kecil (KUK) mempengaruhi kinerja bank.

Hipotesis 6 : Likuiditas (LDR) mempengaruhi kinerja bank.

Hipotesis 7 : Profitabilitas (NIM) mempengaruhi kinerja bank.

Hipotesis 8 : Kualitas aset (NPL) mempengaruhi kinerja bank.

Hipotesis 9 : Profitabilitas (ROA) mempengaruhi kinerja bank.

\section{METODE PENELITIAN}

Penelitian dilakukan pada bank seluruh umum di Indonesia dengan menggunakan data sekunder laporan Bank kepada Bank Indonesia sebagai bank sentral di Indonesia, dari tahun 2000 - 2012. 


\section{Operasionalisasi Variabel \\ Kinerja Bank}

Kinerja Bank merupakan tingkat prestasi atau hasil nyata yang mampu dicapai oleh bank selama periode waktu tertentu, yang dipengaruhi oleh kegiatan operasional bank dalam memanfaatkan, mengelola, dan mengendalikan sumber daya yang dimiliki bank.

Dalam penelitian ini, informasi ukuran kinerja bank digunakan rasio RORWA (Return on Risk Weighted Assets).

RORWA lebih cocok sebagai pengukur kinerja karena pengukur kinerja yang lain mungkin lebih tepat dalam memahami risiko secara teoritis, tetapi tidak praktis untuk digunakan dalam mengelola bank. Kekuatan RORWA terletak pada pemahamannya yang baik yang menggunakan Aset Tertimbang Menurut Risiko (ATMR) sebagai pembagi, sehingga membuat RORWA menjadi proxy yang baik dan tepat dalam memahami risiko.

Indikator pengukuran kinerja (RORWA) menurut Sinn, Acunto, dan Oldrini (2013) dapat diperoleh dengan melakukan perhitungan sebagai berikut:

$$
\text { RORWA }=\frac{\text { Pre Tax Operating Results }}{\text { Total Risk Weighted Assets }} \times 100 \%
$$

\section{Tingkat Efisiensi}

Tingkat Efisiensi adalah indikator yang digunakan untuk mengukur kondisi operasional perusahaan dan kemampuan perusahaan dalam menggunakan aset-aset dan sumber daya yang dimilikinya untuk mencapai kesuksesan, kinerja keuangan yang sehat dan berkelanjutan, serta kenaikan pendapatan dan kinerjabank.

Dalam penelitian ini, informasi tingkat efisiensidigunakan rasio BOPO (Biaya Operasional terhadap Pendapatan Operasional).Informasi indikator pengukuran efisiensi(BOPO) berdasarkan Pedoman Rasio Keuangan dalam lampiran Surat Edaran Bank Indonesia Nomor 7/10/DPNP adalah sebagai berikut:

$$
B O P O=\frac{\text { Total Beban Operasional }}{\text { Total Pendapatan operasional }}
$$

\section{Tingkat Modal}

Tingkat Modal merupakan modal dimiliki bank, yang digunakan untuk melindungi bank dari kemungkinan penurunan nilai aset, yang dapat mendorong bank memiliki kewajiban yang lebih besar daripada asetnya.

Dalam penelitian ini, informasi tingkat modaldigunakan rasio CAR (Capital Adequacy Ratio)sebagai indikator pengukuran modal. Indikator tingkat modal (CAR) berdasarkan Peraturan Bank Indonesia Nomor 10/15/PBI/2008 adalah sebagai berikut:

$$
C A R=\frac{\text { Modal Inti }+ \text { Modal Pelengkap }}{\text { ATMR Resio Kredit }+ \text { Resiko Pasar }+ \text { Resiko Operasional }}
$$

\section{Tingkat Deposito}

Tingkat Deposito merupakan tingkat simpanan pihak ketiga kepada bank yang penarikannya hanya dapat dilakukan pada jangka waktu tertentu menurut perjanjian antara pihak nasabah pemilik simpanan dengan pihak bank yang bersangkutan. 
Dalam penelitian ini, informasi tingkat deposito digunakan dua rasio sebagai indikator pengukuran deposito. Rasio yang pertama adalah rasio total deposito terhadap total aset (DEPOSIT) sebagai indikator pengukuran tingkat deposito. Indikator pengukuran tingkat deposito (DEPOSIT) menurut Acaravci dan Calim (2013) adalah sebagai berikut:

$$
\text { Deposit }=\frac{\text { Total Deposits }}{\text { Total Assets }}
$$

Sedangkan rasio yang kedua adalah rasio total deposito terhadap total kewajiban (DEPOSIT FUNDING) sebagai indikator pengukuran pendanaan dari deposito. Indikator pengukuran pendanaan dari deposito (DEPOSIT FUNDING) menurut Mergaerts dan Vennet (2015) adalah sebagai berikut:

$$
\text { Deposit Funding }=\frac{\text { Total Deposits }}{\text { Total Liabilities }}
$$

\section{Tingkat Pembiayaan Usaha Kecil}

Pembiayaan Usaha kecil adalah kegiatan usaha ekonomi rakyat berskala kecil yang produktif, yang dimiliki orang perorangan dan / atau badan usaha perorangan dengan jumlah tenaga kerja 5 sampai dengan 19 orang.

Dalam penelitian ini, informasi pembiayaan usaha kecildigunakan rasio total kredit yang diberikan untuk usaha kecil terhadap total kredit yang disalurkan sebagai indikator pengukuran pembiayaan usaha kecil. Indikator pengukuran pembiayaan usaha kecil (KUK) menurut Williams (2012) adalah sebagai berikut:

$$
K U K=\frac{\text { Total Kredit } K U K}{\text { Total kredit yang disalurkan }}
$$

\section{Tingkat Likuiditas}

Informasi Tingkat Likuiditas digunakan rasio LDR (Loan to Deposit Ratio) sebagai indikator pengukuran likuiditas. Indikator pengukuran likuiditas (LDR) berdasarkan Pedoman Rasio Keuangan dalam lampiran Surat Edaran Bank Indonesia Nomor 3/30/DPNP dan Surat Edaran Bank Indonesia Nomor 7/10/DPNP adalah sebagai berikut:

Keterangan:

$$
L D R=\frac{\text { Kredit }}{\text { Dana Pihak Ketiga }}
$$

- Kredit merupakan total kredit yang diberikan kepada pihak ketiga.

- Dana pihak ketiga mencakup giro, tabungan, deposito.

\section{Tingkat Profitabilitas}

Informasi Tingkat Profitabilitas digunakan dua rasio sebagai indikator pengukuran profitabilitas. Rasio yang pertama adalah NIM (Net Interest Margin) sebagai indikator pengukuran profitabilitas. Indikator pengukuran profitabilitas (NIM) berdasarkan Pedoman Rasio Keuangan dalam lampiran Surat Edaran Bank Indonesia Nomor 3/30/DPNP adalah sebagai berikut: 


$$
N I M=\frac{\text { Pendapatan bunga bersih }}{\text { Rata }- \text { rata aktiva produktif }}
$$

Keterangan:

- Pendapatan bunga bersih = Pendapatan bunga - beban bunga

Sedangkan rasio yang kedua adalah ROA (Return On Assets) sebagai indikator pengukuran profitabilitas. Indikator pengukuran profitabilitas (ROA) berdasarkan Pedoman Rasio Keuangan dalam lampiran Surat Edaran Bank Indonesia Nomor 3/30/DPNP adalah sebagai berikut:

$$
R O A=\frac{\text { Laba sebelum pajak }}{\text { Rata }- \text { rata total aset }}
$$

\section{Tingkat Kualitas Aset}

Kualitas aset merupakan indikator penilaian jenis-jenis aktiva yang dimiliki bank, yang digunakan untuk mengukur perubahan kualitas dan risiko pinjaman, serta mengukur besarnya aktiva produktif yang mempunyai risiko kerugian dari kredit bermasalah.

Dalam penelitian ini, informasi kualitas asetdigunakan rasio Net NPL (Net Non-Performing Loan) sebagai indikator pengukuran kualitas aset. Indikator pengukuran kualitas aset (Net NPL) Berdasarkan Pedoman Rasio Keuangan dalam lampiran Surat Edaran Bank Indonesia Nomor 3/30/DPNP dan Surat Edaran Bank Indoensia No. 7/10/DPNP adalah sebagai berikut:

$$
\text { Net NPL }=\frac{\text { Kredit bermasalah }- \text { PPA Produktif }}{\text { Total Kredit }}
$$

Keterangan:

- Kredit merupakan kredit yang diberikan kepada pihak ketiga (tidak termasuk kredit kepada bank lain).

- Kredit bermasalah adalah kredit dengan kualitas Kurang Lancar (KL), Diragukan (D), dan Macet (M).

- PPA Produktif adalah singkatan dari Penyisihan Penghapusan Aktiva Produktif.

- PPA Produktif adalah PPA produktif yang telah dibentuk untuk kredit dengan kualitas Kurang Lancar (KL), Diragukan (D), dan Macet (M).

\section{Teknik Analisis Data}

Teknik analisis data yang dipakai dalam penelitian ini adalah analisis regresi linier berganda. Jenis data yang digunakan dalam penelitian ini adalah data panel. Data dikumpulkan dari 105 bank selama periode 2000-2012, kemudian data diolah dengan menggunakan perangkat lunak pengolahan data E-Views 9.

\section{Statistik Deskriptif}

Statistik deskriptif menggambarkan keadaan awal dari variabel independen dan variabel dependen yang diteliti. Bukti awal mengenai nilai rata-rata (mean), nilai tengah (median), nilai maksimum, nilai minimum, dan standar deviasi. Pengolahan statistic deskriptif menggunakan perangkat lunak pengolahan data yaitu E-Views 9. 


\section{Analisis Regresi Linier Ganda}

Informasi BOPO (Biaya Operasional terhadap Pendapatan Operasional), CAR (Capital Adequacy Ratio), DEP (Deposit), DEPFUN (Deposit Funding), KUK (Kredit Usaha Kecil), LDR (Loan to Deposit Ratio), NIM (Net Interest Margin), NPL (Non-Performing Loans), dan ROA (Return On Assets) terhadap kinerja bank yang diukur dengan RORWA (Return On Risk Weighted Assets).

$$
\begin{aligned}
& \text { RORWA }_{\mathrm{i}(\mathrm{t}+1)}=\alpha+\beta_{1} \text { BOPO }_{\mathrm{it}}+\beta_{2} \text { CAR }_{\mathrm{it}}+\beta_{3} \text { DEP }_{\mathrm{it}}+\beta_{4} \\
& \text { DEPFUN }_{\mathrm{it}}+\beta_{5} \text { KUK }_{\mathrm{it}}+\beta_{6} \mathrm{LDR}_{\mathrm{it}}+\beta_{7} \mathrm{NIM}_{\mathrm{it}}+\beta_{8} \mathrm{NPL}_{\mathrm{it}}+\beta_{9} \text { ROA }_{\mathrm{it}}+e
\end{aligned}
$$

Keterangan:

- RORWA $_{\mathbf{i}(\mathbf{t}+\mathbf{1})}=$ Return on Risk Weighted Assets

- $\quad$ BOPO $_{\text {it }}=$ Biaya Operasional terhadap Pendapatan Operasional

- $\mathbf{C A R}_{\mathbf{i t}}=$ Capital Adequacy Ratio

- DEP $_{\mathbf{i t}}=$ Deposit

- DEPFUN $_{\mathrm{it}}=$ Deposit Funding

- $\quad \mathbf{K U K}_{\mathbf{i t}}=$ Kredit Usaha Kecil

- $\quad \mathbf{L D R}_{\mathbf{i t}}=$ Loan to Deposit Ratio

- $\quad \mathbf{N I M}_{\mathbf{i t}}=$ Net Interest Margin)

- $\mathbf{N P L}_{\mathbf{i t}}=$ Non-Performing Loans

- $\mathbf{R O A}_{\mathbf{i t}}=$ Return On Assets

- $\boldsymbol{e}=$ error

\section{Statistik Deskriptif data penelitian}

\section{ANALISIS DAN PEMBAHASAN}

\section{a. RORWA (Return On Risk Weighted Assets)}

RORWA bank di Indonesia dari -0.1746370 sampai 0.190590 . Nilai rata-rata variabel RORWA yaitu sebesar 0.024483 dengan standar deviasi sebesar 0.026565. Variasi RORWA perbankan di Indonesia rata-rata menunjukkan bahwa adanya

kesenjangan yang cukup besar antara nilai maksimum dan nilai minimum nya. Variasi RORWA perbankan di Indonesia cukup besar.

b. BOPO (Biaya Operasional terhadap Pendapatan Operasional)

BOPO bank dari 0.090900 sampai 1.493300. Nilai rata-rata variabel BOPO yaitu sebesar 0.815131 dengan standar deviasi sebesar 0.135277. Variasi BOPO perbankan di Indonesia kecil.

c. CAR (Capital Adequacy Ratio)

CAR perbankan di Indonesia dari -0.176300 sampai 1.079300. Rata-rata variabel CAR sebesar 0.216178 dengan standar deviasi sebesar 0.124245. Variasi CAR perbankan di Indonesia besar

\section{d. DEP (Deposit)}

DEP dari 0.012126 sampai 0.891468 . Nilai rata-rata variabel DEP sebesar 0.432011 dengan standar deviasi sebesar 0.214144. Variasi DEP besar.

e. DEPFUN (Deposit Funding)

DEPFUN dari 0.014434 sampai 0.952646. Rata-rata variabel DEPFUN sebesar 0.494964 dengan standar deviasi variabel DEPFUN sebesar 0.244645 . Rata-rata variasi variabel DEPFUN cukup besar.

\section{f. KUK (Kredit Usaha Kecil)}


KUK dari 0.000100 sampai 1.458600. Rata-rata variabel KUK yaitu sebesar 0. 195609 dengan standar deviasi sebesar 0.229884. Rata-rata KUK perbankan di Indonesia bervariasi sangat besar.

g. LDR (Loan to Deposit Ratio),

LDR dari 0.100000 sampai 1.496067. Rata-rata variabel LDR sebesar 0.730138 dengan standar deviasi sebesar 0.220899. Variasi LDR sedang

h. NIM (Net Interest Margin)

NIM dari -0.062500 sampai 0.989700. Rata-rata variabel NIM sebesar 0.073257 dengan standar deviasi sebesar 0.048904. Rata-rata NIM perbankan di Indonesia kecil dengan variasi yang besar.

i. NPL (Non-Performing Loans)

NPL dari -0.033900 sampai 0.242900. Rata-rata variabel NPL sebesar 0.019033 dengan standar deviasi sebesar 0.022371. NPL perbankan di Indonesia cuckup besar dengan variasi besar..

j. ROA (Return On Assets).

ROA dari -0.136700 sampai 0.200000. Rata-rata variabel ROA sebesar 0.025061 dengan standar deviasi sebesar 0.020255. Rata-rata ROA perbankan di Indonesia kecil dengan variasi yang yang besar.

Tabel 2. Statistik Deskriptip Data Penelitian

\begin{tabular}{|c|c|c|c|c|c|}
\hline & RORWA & BOPO & CAR & DEP & DEPFUN \\
\hline Mean & 0.024483 & 0.815131 & 0.216178 & 0.432011 & 0.494964 \\
\hline Median & 0.019524 & 0.819900 & 0.180000 & 0.441983 & 0.507884 \\
\hline Maximum & 0.190590 & 1.493300 & 1.079300 & 0.891468 & 0.952646 \\
\hline Minimum & -0.174637 & 0.090900 & -0.176300 & 0.012126 & 0.014434 \\
\hline Std. Dev. & 0.026565 & 0.135277 & 0.124245 & 0.214144 & 0.244645 \\
\hline Skewness & 0.279951 & 0.021866 & 2.910700 & -0.091468 & -0.149066 \\
\hline Kurtosis & 13.34331 & 5.019712 & 14.51289 & 1.854595 & 1.806910 \\
\hline & & & & & \\
\hline Jarque-Bera & 6947.517 & 264.2544 & 10776.69 & 87.11586 & 97.92439 \\
\hline Probability & 0.000000 & 0.000000 & 0.000000 & 0.000000 & 0.000000 \\
\hline & & & & & \\
\hline Sum & 38.04640 & 1266.714 & 335.9413 & 671.3458 & 769.1744 \\
\hline Sum Sq. Dev. & 1.095921 & 28.41986 & 23.97342 & 71.21669 & 92.94914 \\
\hline Observations & 1554 & 1554 & 1554 & 1554 & 1554 \\
\hline
\end{tabular}

\begin{tabular}{|c|c|c|c|c|c|}
\hline & KUK & LDR & NIM & NPL & ROA \\
\hline Mean & 0.195609 & 0.730138 & 0.073257 & 0.019033 & 0.025061 \\
\hline Median & 0.109100 & 0.752058 & 0.063800 & 0.013300 & 0.022700 \\
\hline Maximum & 1.458600 & 1.496067 & 0.989700 & 0.242900 & 0.200000 \\
\hline Minimum & 0.000100 & 0.100000 & -0.062500 & -0.033900 & -0.136700 \\
\hline Std. Dev. & 0.229884 & 0.220899 & 0.048904 & 0.022371 & 0.020255 \\
\hline Skewness & 1.909161 & -0.035622 & 10.22570 & 3.583421 & 0.744588 \\
\hline Kurtosis & 6.347264 & 3.185896 & 174.0641 & 23.23900 & 11.99079 \\
\hline & & & & & \\
\hline Jarque-Bera & 1669.499 & 2.566232 & 1921856. & 29848.50 & 5377.615 \\
\hline Probability & 0.000000 & 0.277172 & 0.000000 & 0.000000 & 0.000000 \\
\hline & & & & & \\
\hline Sum & 303.9761 & 1134.634 & 113.8418 & 29.57748 & 38.94514 \\
\hline Sum Sq. Dev. & 82.07080 & 75.78082 & 3.714217 & 0.777233 & 0.637119 \\
\hline Observations & 1554 & 1554 & 1554 & 1554 & 1554 \\
\hline
\end{tabular}




\section{Analisis Regresi Linier Berganda}

Tabel 2. Analisis Regresi Linier Berganda

Dependent Variable: RORWA

Method: Robust Least Squares

Included observations: I554

\begin{tabular}{|c|c|c|c|c|}
\hline Variable & Coefficient & Std. Error & z-Statistic & Prob. \\
\hline $\mathrm{C}$ & 0.048546 & 0.003616 & $\mathrm{I} 3.42732$ & 0.0000 \\
\hline $\mathrm{BOPO}$ & -0.032028 & 0.003684 & -8.694935 & 0.0000 \\
\hline CAR & 0.020018 & 0.003801 & 5.266924 & 0.0000 \\
\hline DEP & 0.050826 & 0.012103 & $4.1995 \mathrm{I} 4$ & 0.0000 \\
\hline DEPFUN & $-0.05636 \mathrm{I}$ & 0.010533 & -5.350686 & 0.0000 \\
\hline KUK & 0.006152 & 0.001314 & 4.682630 & 0.0000 \\
\hline LDR & -0.011550 & 0.001534 & -7.530412 & 0.0000 \\
\hline NIM & -0.024573 & 0.006413 & $-3.83157 \mathrm{I}$ & 0.0001 \\
\hline NPL & -0.054375 & 0.013508 & -4.025448 & $0.000 \mathrm{I}$ \\
\hline \multirow[t]{2}{*}{$\mathrm{ROA}$} & 0.475422 & 0.023595 & 20.14955 & 0.0000 \\
\hline & \multicolumn{4}{|c|}{ Robust Statistics } \\
\hline R-squared & 0.435195 & \multicolumn{2}{|c|}{ Adjusted R-squared } & 0.431903 \\
\hline $\mathrm{R}_{W \text {-squared }}$ & 0.690553 & \multicolumn{2}{|c|}{ Adjust Rw-squared } & 0.690553 \\
\hline Akaike info criterion & I981.887 & \multicolumn{2}{|c|}{ Schwarz criterion } & 2038.714 \\
\hline Deviance & 0.197505 & \multicolumn{2}{|l|}{ Scale } & 0.010025 \\
\hline \multirow[t]{2}{*}{ Rn-squared statistic } & $3 \mathrm{I} 28.454$ & \multicolumn{2}{|c|}{ Prob(Rn-squared stat.) } & 0.000000 \\
\hline & \multicolumn{4}{|c|}{ Non-robust Statistics } \\
\hline Mean dependent var & 0.024483 & \multicolumn{2}{|c|}{ S.D. dependent var } & 0.026565 \\
\hline S.E. of regression & 0.018718 & \multicolumn{2}{|c|}{ Sum squared resid } & 0.540945 \\
\hline
\end{tabular}

Sumber : hasil pengolahan data menggunakan E-Views 9

Berdasarkan Tabel 2 disusun model regresi linier berganda sebagai berikut:

RORWA $_{i(t+1)}=0.048546-0.032028$ BOPO $_{i t}+0.020018$ CAR $_{i t}+0.050826$ DEP $_{i t}-$ 0.056361 DEPFUN $_{\text {it }}+0.006152 \mathbf{K U K}_{\mathbf{i t}}-0.011550 \mathbf{L D R}_{\mathbf{i t}}-0.024573 \mathbf{N I M}_{\mathbf{i t}}-0.054375$ NPL $_{i t}+0.475422$ ROA $_{\text {it }}$

\section{Uji Hipotesis}

Dengan tingkat alpha $(\alpha)<0.05$ uji hipotesis menggunakan hasil analisis pada Tabel 2 sebagai berikut

\section{a) Hipotesis 1}

Nilai probabilitas BOPO lebih kecil dari alpha $(\alpha)$ yaitu $0.0000<0.05$ maka $\mathrm{Ho}_{1}$ ditolak. Tingkat efisiensi (BOPO) signifikan negatif mempengaruhi kinerja bank.

b) Hipotesis 2

Nilai probabilitas CAR lebih kecil dari alpha $(\alpha)$ yaitu $0.0000<0.05$ maka $\mathrm{Ho}_{2}$ ditolak. Tingkat modal (CAR) signifikan positif mempengaruhi kinerja bank.

c) Hipotesis 3

Nilai probabilitas DEPOSIT lebih kecil dari alpha $(\alpha)$ yaitu $0.0000<0.05$ maka $\mathrm{Ho}_{3}$ ditolak.

Tingkat deposito (DEPOSIT) signifikan positif mempengaruhi kinerja bank. 


\section{d) Hipotesis 4}

Nilai probabilitas DEPOSIT FUNDING lebih kecil dari alpha $(\alpha)$ maka $\mathrm{Ho}_{4}$ ditolak. Tingkat deposito (DEPOSIT FUNDING) signifikan negatif mempengaruhi kinerja bank.

\section{e) Hipotesis 5}

Nilai probabilitas KUK lebih kecil dari alpha $(\alpha)$ maka Ho $_{5}$ ditolak.

Pembiayaan usaha kecil (KUK) signifikan positif mempengaruhi kinerja bank.

\section{f) Hipotesis 6}

Nilai probabilitas LDR lebih kecil dari alpha $(\alpha)$ maka $\mathrm{Ho}_{6}$ ditolak. Likuiditas (LDR) signifikan negatif mempengaruhi kinerja bank.

\section{g) Hipotesis 7}

Nilai probabilitas NIM lebih kecil dari alpha $(\alpha)$ maka $\mathrm{Ho}_{7}$ ditolak. Profitabilitas (NIM) signifikan negatif mempengaruhi kinerja bank.

\section{h) Hipotesis 8}

Nilai probabilitas NPL lebih kecil dari alpha $(\alpha)$ maka $\mathrm{Ho}_{8}$ ditolak. Kualitas aset (NPL) signifikan negatif mempengaruhi kinerja bank.

\section{i) Hipotesis 9}

Nilai probabilitas ROA lebih kecil dari alpha $(\alpha)$ maka $\mathrm{Ho}_{9}$ ditolak. Profitabilitas (ROA) signifikan positif mempengaruhi kinerja bank.

Nilai Adjust Rw-squared nya sebesar 0.690553 menunjukkan kecocokan model penelitian $69,06 \%$. Sisanya 30,94 \% model kinerja bank ditentukan oleh tingkat risiko, peraturan perbankan nasional, kepemilikan bank, keputusan manajemen, dewan, ukuran bank, diversifikasi pendapatan, komposisi aset, struktur pasar, total aset, tier-one capital, tata kelola perusahaan, tingkat suku bunga, tingkat inflasi, non-interest expenses, kualitas pelayanan, produktivitas tenaga kerja, dan faktor lain nya.

\section{PEMBAHASAN}

Hasil penelitian mencatat bahwa efisiensi, modal, deposito, pembiayaan usaha kecil, likuiditas, kualitas aset, dan probabilitas signifikan mempengaruhi kinerja bank.Informasi kegiatan bank yang terus menerus dimonitor akan menghasilkan kinerja yang meningkat.Dalam hal ini Bank Indonesia sebagai bank sentral efektif mengendalikan perbankan dengan mengharuskan perbankan memberikan laporan yang diwajibkan ( dalam studi ini informasi RORWA, BOPO, CAR, Deposito, Depfund, KUK, LDR, NIM, NPL, dan ROA) karena hasil penelitian menunjukkan ternyata perbankan di Indonesia menggunakan informasi tersebut dalam mengendalikan manajemen perbankannya.

Konsisten dengan literatur penelitian (Hamada, dan Konishi, 2010) BOPO signifikan negatif mempengaruhi kinerja bank. Di Eropa dan dibagian Negara lainnyakonsisten mencatat bukti bahwa bank dengan efisiensi yang lebih tinggi mempunyai kinerja bank yang lebih baik dibandingkan dengan bank-bank lain (Fiserova, Teply, dan Tripe, 2015;.Olweny dan Shipo, 2011;). Semakin tinggi rasio BOPO maka semakin rendah kinerja bank tersebut, bank yang tidak bekerja secara efisienakan menghasilkan kinerja yang rendah. Sebaliknya semakin kecil rasio BOPO maka semakin tinggi kinerja bank tersebut, bank yang bekerja secara efisienakan menghasilkan kinerja yang tinggi. Pengendalian biaya operasi melalui laporan BOPO setiapperiode operasi, akan meningkatkan efisiensi sehingga kinerja periode berikutnya akan meningkat. Pemantauan secara periodik informasi kegiatan dan posisi bank dan melakukan pengendalian yang relevan akan meningkatkan kinerja. Perbaikan dan penyesuaian terhadap kegiatanyang relevan akan mempengaruhi kinerja secara keseluruhan. Perubahan konteks pada 
perekonomian dan fenomena operasional yang berubah dengan cepat, terutama setelah terjadinya krisis global, akanmembutuhkan penyesuaian-penyesuaian sesuai dengan konteks yang terjadi pada lingkungan bisnis Perbankan. Pemantauan informasi BOPO ditindak lanjuti perbankan di Indonesia dengan melakukan perbaikan manajemen operasional nya sehingga tingkat BOPO akan makin sesuai dengan tingkat operasi bank, sekali gusmeningkatkan kinerja bank.

Konsisten dengan literatur penelitian mencatat bahwa tingkat kecukupan modal yang diukur dengan rasio kecukupan modal atau Capital Adequacy Ratio (CAR) signifikan positif mempengaruhi kinerja bank (Mergaerts dan Vennet, 2015;Dietrich dan Wanzenried, 2009;AlTamimi dan Charif, 2011 ; Sakinc dan Gulen, 2014). Kecukupan modal terbukti penting dalam meningkatkan kinerja. Bank yang memiliki CAR yang tinggi dapat mendukung kinerja bank, dan semakin tinggi CAR nya, semakin tinggi pula kinerja bank tersebut. Akan tetapi, masih tidak konsisiten dengan yang terjadi di Negeria. CAR ternyata tidak signifikan mempengaruhi kinerja bank (Onaolapo dan Olufemi, 2012). Hal ini terjadi karena pengendalian atau penyesuaian CARtidak dilakukan setiap saat atau periode. Informasi CAR tidak dipantau dan tidak dikendalikan, sehingga CAR tidak mempengaruhi kinerja periode berikutnya. Informasi CAR pada periode sebelumnya bila dimonitor dan digunakan untuk pengendalian manajemen perbankan secara keseluruhan akan menghasilkan peningkatan kinerja. Pentingnya pengendalian kinerja melalui informasi setiap periode menggambarkan atau sebagai implikasi dari hasil studi ini.

Konsisten dengan literaturpenelitian bahwa tingkat deposito memiliki dampak yang signifikan terhadap kinerja bank, termasuk pada bank BUMN (Badan Usaha Milik Negara) (Acaravci dan Calim, 2013;.Tunali, dkk, 2015; ). Bank yang memiliki tingkat deposito yang tinggi, memiliki kinerja yang tinggi pula. Sumber dana deposito menjadi penentu dalam pencetakkan aset bank sesuai dengan peraturan bank sentral. Pengendalian tingkat deposito setiap periode akan memudahkan manajemen perbankan menyesuaikan pencetakan asetnyadengan memberikan kredit kepada pengusaha seimbang denganpertumbuhan perekonomian untuk periode berikutnya, sehingga kinerja akan meningkat. Informasi tingkat deposito perlu selalu dimonitor agar dapat dilakukan penyesuaian yang dibutuhkan setiap saat atau setiap periode. Pembuatan informasi setiap periodeakan memudahkan manajemen melalukan analisis dan memperbaiki strategi operasional dan atau pengalokasian aset bank nya. Akibatnya kinerja bank akan dipengaruhi tingkat CAR nya.

Konsisten dengan literatur penelitian komposisi pendanaan yang diukur dengan menggunakan rasio total deposito nasabah terhadap total kewajiban signifikan negatif mempengaruhi kinerja bank (Mergaerts dan Vennet, 2015;Gatev dkk, 2009) bank-bank yang memiliki deposito nasabah memungkinkan mereka untuk mengambil manfaat dari kegiatan pinjaman mereka. Hal ini juga menunjukkan bahwa bank tersebut memiliki ketergantungan yang kuat dari deposito nasabah bila ingin meningkatkan profitabilitas, sehingga apabila rasio total deposito nasabah terhadap total kewajiban menjadi meningkat maka kinerja bank akan mengalami penurunan. Semakin besar DEPFUN semakin tinggi sumber dana menggunakan deposito nasabah sehingga akan menurunkan kinerja bank. Perlu pemantauan terhadap tingkat depfund ini. Informasi yang disampaikan kepada Bank Indonesia sebagai laporan bank rutin terhadap tingkat Depfund bank akan memberikan informasi kepada perbankan untuk melakukan pengendalian terhadap DEPOSITO sebagai sumber dana bank. Penyesuaian yang relevan membuat tingkat Depfund ini mempengaruhi kinerja bank. 
Konsisten dengan literatur penelitian, pembiayaan usaha kecil signifikan positif mempengaruhi kinerja bank di Indonesia (Anwar, 2010;) Namun studi initidak konsisten di Amerikakarena di Amerika pembiayaan usaha kecil tidak mempengaruhi kinerja bank (Ergungor, 2002). Penggunaan nilai kredit untuk pinjaman usaha kecil memiliki efek awal yang negatif pada kinerja bank, dan efek yang moderat dari waktu ke waktu (Berger, Cowan, dan Frame, 2011). Di Indonesia direncanakan UKM (Usaha Kecil dan Menengah) yang merupakan salah satu bidang usaha yang ditekuni oleh mayoritas masyarakat Indonesia akan menggerakkan roda perekonomiannya. Selain itu, pemerintah Indonesia aktif mendukung penyaluran kredit bagi para pelaku UKM. Oleh karena itu, dengan meningkatnya rasio pembiayaan usaha kecil akan meningkatkan kinerja bank. UKM terbukti dapat memberikan kontribusi kepada kinerja bank. Informasi tingkat KUK kepada UKM setiap periode memberikan perbankan kesempatan memonitor dan mengendalikan KUK sehingga UKM dapat berprestasi dan memberikan kontribusi kepada kinerja bank.

Konsisten dengan literatur penelitian (Shen, dkk, 2009) likuiditas signifikan negatif mempengaruhi kinerja bank. Rendahnya likuiditas menyebabkan bank harus melakukan pinjaman jangka pendek antar bank, atau mencari alat likuid lain yang biasanya memiliki biaya lebih tinggi dibandingkan dengan dana pihak ketiga (deposito). Hal tersebut mengakibatkan menurunnya pendapatan bank sehingga berdampak pada penurunan kinerja bank. Semakin rendah likuiditas maka semakin rendah pula kinerja bank tersebut. Manjemen likuiditas dapat mempengaruhi kinerja bank. Informasi periode sebelumnya digunakan untuk memanajemeni likuiditas sehingga operasional bank dapat melakukan penyesuaian. Informasi likuiditas setiap periode ternyata digunakan perbankan guna mengambil keputusan yang relevan pada periode selanjutnya, dan akibatnya mempengaruhi kinerja bank.

Konsisten dengan literatur penelitian NIM negatif signifikan mempengaruhi kinerja bank (Hamada dan Konishi, 2010), namun di Tiongkok NIM positif signifikan mempengaruhi kinerja bank (Li, dkk, 2001). Dalam penelitian Li, dkk (2001) dicatat kinerja bank yang rendah diakibatkan oleh rendahnya rasio NIM dari bank tersebut. Pendapatan dari bunga masih mendominasi pendapatan bank tersebut. Sementara di Indonesia dan beberapa Negara NIM negatif mempengaruhi kinerja bank. Informasi NIM dibuat dan digunakan untuk mengendalikan kinerja bank.

Konsisten dengan literatur penelitian (Andries, Vasile, dan Maria, 2011) kualitas aset signifikan mempengaruhi kinerja bank. Penurunan total kredit macet akan menurunkan rasio NPL, dan semakin rendah rasio NPL maka kinerja bank akan meningkat karena fungsi bank sebagai lembaga intermediary sudah berjalan dengan baik. Sebaliknya, peningkatan total kredit macet akan meningkatkan rasio NPL, dan semakin tinggi rasio NPL maka kinerja bank akan menurun karena fungsi bank sebagai lembaga intermediary tidak berjalan dengan baik dan bank dinilai gagal dalam menjalankan fungsinya tersebut. Informasi secara periodik tentang NPL tidak hanya untuk pelaporan yang wajib disampaikan kepad Bank Indonesia sebagai bank sentral, namun digunakan juga oleh perbankan di Indonesia untuk mengendalikan kegiatan pemberian kredit dari waktu ke waktu.

Konsisten dengan literatur penelitian (Hamada dan Konishi, 2010; )tingkat ROA mempengaruhi kinerja bank. Sebagian besar penelitian mengenai kinerja bank menggunakan ROA (Return on Assets) dan ROE (Return on Equity) sebagai indikator perbankan untuk mengukur kinerja bank. Akan tetapi, penelitian berbeda yang dilakukan oleh Dogan (2013), ROA memiliki pengaruh yang lebih besar dibandingkan dengan ROE dan bahkan ROA memiliki sebagian pengaruh dari 
pengaruh rasio lainnya terhadap kinerja bank. Dengan kata lain, indikator perbankan yang paling penting dalam keberhasilan finansial bank adalah rasio profitabilitas, terutama ROA. Berdasarkan penelitian di Turki yang dilakukan oleh Zhang, dkk (2013), bank dengan ROA yang tinggi juga memiliki kinerja keuangan yang tinggi.

Selama ini pengukuran kinerja yang diterapkan oleh perbankan menggunakan pendekatan tradisional. Perbankan lebih banyak menggunakan pengukuran kinerja dengan pendekatan tradisional, yaitu pengukuran kinerja yang menekankan pada aspek keuangan yang diukur secara periodik. Dalam pengukuran kinerja tradisional, hal yang diukur hanyalah hal yang berkaitan dengan aspek keuangan saja, sedangkan pengukuran kinerja lainnya seperti peningkatan kompetensi dan komitmen sumber daya manusia, peningkatan produktivitas, dan proses bisnis yang digunakan untuk melayani pelanggan, menjadi hal yang selalu diabaikan oleh pihak manajemen bank karena pengukurannya masih sulit dilaksanakan.

Akan tetapi, pada era globalisasi saat ini bisnis perbankan menghadapi persaingan yang ketat, bank-bank bersaing dalam dunia bisnis yang kompleks dan penuh tantangan sehingga pemahaman konsep tentang memenangkan persaingan bisnis merupakan hal yang sangat penting. Berbagai usaha dilakukan oleh bank agar dapat memenangkan persaingan bisnis dalam dunia bisnis perbankan yang kompetitif. Oleh karena itu, bank diharapkan dapat mewujudkan strategi-strategi bisnis jangka panjang agar dapat bertahan hidup. Untuk menjaga kelangsungan hidup sebuah bank, bank harus memiliki keunggulan bersaing yang mampu memenuhi atau memuaskan kebutuhan para nasabah-nasabahnya. Oleh karenanya sistem manajemen strategi dalam perbankan perlu diterapkan dan ditingkatkan, walau pergerakan industri perbankan diatur secara ketat oleh bank sentral. Disamping pengendalian manajemen melalui informasi yang diregulasi ketat perbankan juga dituntut meningkatkan sistem pengendalian pertumbuhan kinerja melalui sistem manajemen strategi agar dapat dicapai keunggulan bersaing.

Persaingan bisnis antar bank yang semakin ketat mengharuskan setiap bank untuk menawarkan pelayanan yang terbaik kepada para nasabahnya, baik pelayanan produk maupun pelayanan jasa. Di samping itu, kunci persaingan dalam bisnis perbankan adalah kualitas penuh yang mencakup kualitas produk, kualitas biaya, dan kualitas pelayanan. Informasi secara periodik selain digunakan untuk penyampaian laporan wajib kepada otoritas perbankan dan bank sentral ( Bank Indonesia ) bila dimanfaatkan akan memberikan kontribusi kepada kinerja bank karena keadaanlingkungan yang terus berkembang sehingga berguna memberikan kepuasan kepada para nasabahnya dan meningkatkan kinerja.

Pengukuran kinerja bank yang dilakukan melalui pendekatan tradisional sudah tidak relevan untuk dijadikan tolak ukur yang kuat pada era globalisasi yang penuh dengan persaingan. Pengukuran kinerja dengan pendekatan tradisional ini menyebabkan bank hanya berorientasi pada keuntungan jangka pendek, dan cenderung mengabaikan kelangsungan hidup bank dalam jangka panjang. Oleh karena itu, bank membutuhkan tolak ukur lain selain aspek keuangan, yaitu aspek non keuangan. Hal tersebut diperlukan oleh bank untuk dapat mengarahkan para manajer pada tujuan bank untuk memperoleh keuntungan jangka panjang, mutu yang tinggi, pelanggan yang loyal, dan kepuasan kerja yang maksimal.

Selain itu, pengukuran kinerja bank secara tradisional memiliki banyak kelemahan. Kelemahan utama, selain hanya berorientasi pada keuntungan jangka pendek dan cenderung mengabaikan kelangsungan hidup bank dalam jangka panjang, adalah ketidakmampuan bank dalam mengukur kinerja dari harta-harta tidak berwujud (intangible assets) dan harta-harta intelektual bank yang 
berupa sumber daya manusia. Di samping itu, kelemahan lainnya dari pengukuran kinerja dengan pendekatan tradisional ini juga kurang mampu bercerita banyak mengenai masa lalu, kurang memperhatikan faktor-faktor eksternal, dan tidak mampu sepenuhnya menuntun bank menuju ke arah tujuan yang ingin dicapai.

Pengukuran kinerja merupakan suatu hal yang penting dalam dunia perbankan, karena dengan melakukan pengukuran kinerja maka perbankan dapat mengetahui tingkat pencapaian yang diraihnya selama periode tertentu. Pengukuran kinerja yang dilakukan oleh perbankan dengan pendekatan tradisional ternyata kurang dapat mengevaluasi kinerja perbankan secara keseluruhan karena pengukuran kinerja dengan pendekatan tradisional hanya mengukur aspek keuangan dan bertumpu pada kinerja keuangan bank pada masa lalu, sehingga pendekatan ini kurang mampu untuk menuntun perbankan ke arah tujuan yang ingin dicapai dan mengabaikan tujuan bank dalam jangka panjang. Selain itu, adanya persaingan bisnis yang ketat dalam dunia perbankan mengharuskan sektor perbankan untuk mengubah pendekatan yang digunakannya untuk mengukur kinerja bank. Oleh karena itu, dalam mengukur kinerja dalam sektor perbankan diperlukan suatu keseimbangan (balanced) antara perspektif keuangan dan perspektif non keuangan.

\section{Simpulan}

Informasi yang diwajibkan oleh Bank Indonesia selain sebagai laporan bankternyata memang digunakan oleh perbankan di Indonesia dalam meningkatkan kinerjanya. Semua informasi yang diteliti digunakan bank dalam mengendalikan kinerjanya. Perbankan di Indonesia tidak hanya mengandalkan interest dalam hasil usahanya, melainkan juga sudah mengandalkan fee base income.

\section{REFERENSI}

Acaravci, Songul Kakilli dan Calim, Ahmet Ertugrul. (2013). Turkish Banking Sector's Profitability Factors. International Journal of Economics and Financial Issues. Vol. 3, No.1. hal. 27-41

Akroush, Mamoun N. (2009). Does service quality implementation mediate the relationship between technical service quality and performance: an empirical examination of banks in Jordan.International Journal of Services, Economics and Management (IJSEM), Vol. 1, No. 3, 2009

Andries Alin Marius, Cocris Vasile, dan Maria Popescu, 2011..The impact of quality of loans on the performance of banks. EuroEconomica Issue 3(Vol, 29)/2011. Hal 1-8

Andries Alin Marius, Cocris Vasile, dan Silviu Gabriel Ursu, 2012. Determinants Of Bank Performance In Cee Countries. journal Review of Economic and Business Studies. Vol 2012 Issue 10. Hal 165-177

Al-Tamimi, Hussein A. H. dan Charif, Husni. (2011). Multiple Approaches In Performance Assessment Of UAE Commercial Banks International Journal of Islamic and Middle Eastern Finance and Management, Vol. 4 Issue: 1, pp.74 82

Altan, Mikail, Habib Yusufazari, dan Aykut Bedük(2014). Performance Analysis Of Banks In Turkey Using Camel ApproachProceeding 14th International Academic Conference, Malta. 28 Oktoner 2014.

Anwar, Mokhamad. (2010). Small Business Financing And Bank Performance : Empirical Study Of Indonesian Publicly Banks Working Papers in Business, Management and Finance, Department of Management and Business, Padjadjaran University.202010, Oktober 2010 
Awdeh, Ali. (2005). Domestic Banks' And Foreign Banks' Profitability: Differences And Their Determinants, Journal Of Banking And Finance, Cass Bussiness School, City Of London 93

Ayadi, Ines dan Ellouze, Abderrazak. (2013). Market Structure And Performance Of Tunisian Banks International Journal of Economics and Financial Issues Vol. 3, No. 2, 2013, pp.345-354

Bai, Ying Shu dan Doowoo Nam. (2009). An Analysis Of The Impacts Of Corporate Governance On The Financial Performance Of The Chinese Banks. Vol. 3. Issue 1

Berger Allen N., Adrian M. Cowan, dan W. Scott Frame, 2011.The Surprising Use of Credit Scoring in Small Business Lending by Community Banks and the Attendant Effects on Credit Availability, Risk, and ProfitabilityJournal of Financial Services Research. April 2011,Volume 39, Issue 1-2, pp 1-17

Csaba Móré dan Márton Nagy, 2004. Competition In The Hungarian Banking Market1. MNB WORKING PAPER 2004/9

Dietrich, Andreas dan Gabrielle Wanzenried. (2009). What Determines The Profitability Of Commercial Banks? New Evidence From Switzerland Journal of International Financial Markets, Institutions and Money Vol 21,Issue3 (July)Pages: 307-327

Dogan, Mesut. (2013). Measuring Bank Performance With Gray Relational Analysis: The Case Of Turkey Ege Academic Review. Vol 13, Issue3 (2013)pages 215-225

Drago, Florea. (2011). Risk And Performance A Purposes Of Banking Supervison And Stability Economic Sciences Series Vol XI, Issue 2, (2011)pages 449-454

Hamada, Miki dan Konishi, Masaru. (2010). Related Lending And Bank Performance: Evidence From Indonesia Institute Of Developing Economies-JETRO Ide Discussion Paper No. 229

Ivanov, Stoyu I. (2014).Performance Analysis Of Banks Headquartered In Hollywood Versus Silicon ValleyGlobal Journal of Business Research.Vol (Year): 8 (2014)Issue: 2 Pages:33-43

Lin, Xiaochi dan Yi Zhang. (2009). Bank Ownership Reform And Bank Performance In China.Journal of Banking \& Finance.Vol.33 (2009)Issue:1.Pages:20-29

Mergaerts, Frederik dan Vennet, R. V. (2016). Business Models And Their Impact On Bank Performance: A Long-Term Perspective.Journal of Financial Stability, 2016, vol. 22, issue $\mathrm{C}$, 57-75

Micco Alejandro, Ugo Panizza and Monica Yañez,(2007) Bank Ownership and Performance Does Politics Matter?Journal of Banking \& Finance.Volume 31, Issue 1, January 2007, Pages 219-241

Odonkor Theodora A., Kofi A. Osei, Joshua Abor, Charles K.D Adjasi. (2011).Bank risk and performance in Ghana. International Journal of Financial Services Management (IJFSM), Vol. 5, No. 2, 2011pages 107-120

Olweny, Tobias dan Themba Mamba Shipo. (2011). Effect Of Banking Sectoral Factors On The Profitability Of Commercial Banks In Kenya. Economics And Finance Review. Vol. 1(5). Pp. 01-30

Onaolapo, A. dan Olufemi, A. F. (2012). Effect Of Capital Adequacy On The Profitability Of Nigerian Banking Sector. Journal Of Money, Investment, And Banking. Issn 1450

Peraturan Bank Indonesia Nomor 10/15/Pbi/2008

Ramli dan Iskandar. (2014). Control Authority, Business Strategy, And The Characteristics Of Management Accounting Information Systems.Procedia - Social and Behavioral Sciences. Volume 164, 31 December 2014, Pages 384-390

Sakinc, Ilker, dan Gulen, Merve. (2014). The Performance Comparison Of The Participation Banks Acting In Turkey Grey Relations Analysis MethodJournal of Economic and social thought vol.1no.1(2014)hal 1-12. 
Shen, Chung-Hua, et. al. (2009). Bank Liquidity Risk And Performancehttps://www.researchgate.net/publication/228366383_Bank_Liquidity_Risk_ and_Performance

Sinn, Walter, Rocco D'Acunto and Andrea Oldrini (2013). European Banking: Striking The Right Balance Between Risk And Return. Frankfurt: Bain And Company (2013)http://www.bain.com/Images/BAIN_REPORT_European_banking.pdf

Sum, Katarzyna. (2015). Banking Regulation And Bank Performance In The Eu And What Should Be The Scope Of The Regulatory Reform? Bank $i$ Kredyt, 2015, vol. 46, issue 3, 207-236

Surat Edaran Bank Indonesia Nomor 3/30/Dpnp

Surat Edaran Bank Indonesia Nomor 7/10/Dpnp

Surat Edaran Bank Indonesia Nomor 13/30/Dpnp Tanggal 16 Desember 2011

Tetyana, M. (2013). Information Provision Of Costs Controlling The Problems of Economy. Volume (Year):(2013)Issue:4 Pages: 375-383

Tunali Duygu, Emel Şiklar, İlknur Tekin(2015). Factors Affecting The Performance Of Turkish Banks 9914 April 2015, 15th International Academic Conference, Rome DOI: 10.20472/IAC.2015.015.186

Undang-Undang No. 10 Tahun 1998 Tentang Perbankan Indonesia

Undang-Undang No. 7 Tahun 1992

Undang-Undang Pokok Perbankan No. 14 Tahun 1967 Tentang Pokok-Pokok Perbankan Indonesia

Undang-Undang Republik Indonesia Nomor 20 Tahun 2008 Tentang Usaha Mikro, Kecil, dan Menengah

Williams, Victoria. (2012). Small Business Lending In The United States 2010-2011 https://www.sba.gov/sites/default/files/files/sbl_12study.pdf

Zhang, Jianhua,BaozhiQu, dan PengWang. (2013). Market Concentration, Risk-Taking, And Bank Performance: Evidence From Emerging Economies International Review of Financial Analysis. Volume 30, December 2013, Pages 149-157

Zhu, Haibin dan Davis, E. Philip. (2009). Commercial Property Prices And Bank Performance. The Quarterly Review of Economics and Finance. Volume 49, Issue 4, November 2009, Pages 1341-1359 